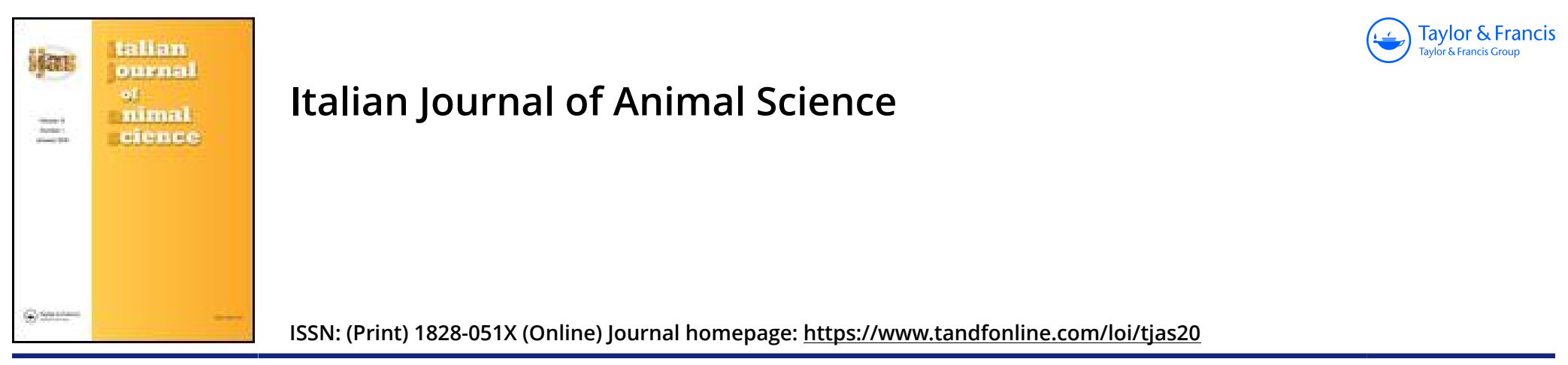

\title{
Post-thaw survival and acrosome integrity of spermatozoa of Leccese rams frozen in different seasons with a milk-egg yolk extender
}

\section{Angela Gabriella D’Alessandro \& Giovanni Martemucci}

To cite this article: Angela Gabriella D'Alessandro \& Giovanni Martemucci (2005) Post-thaw survival and acrosome integrity of spermatozoa of Leccese rams frozen in different seasons with a milk-egg yolk extender, Italian Journal of Animal Science, 4:2, 139-148, DOI: 10.4081/ijas.2005.139

To link to this article: https://doi.org/10.4081/ijas.2005.139

\section{(.) 2005 Taylor \& Francis}

\section{Published online: 01 Mar 2016.}

Submit your article to this journal $\square$

Џll Article views: 68

Q View related articles $₫$ 


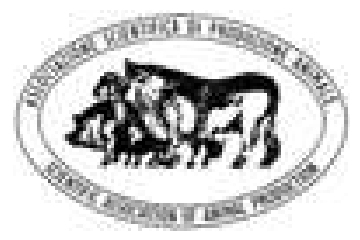

\title{
Post-thaw survival and acrosome integrity of spermatozoa of Leccese rams frozen in different seasons with a milk-egg yolk extender
}

\author{
Angela Gabriella D’Alessandro, Giovanni Martemucci \\ Dipartimento di Progettazione e Gestione dei Sistemi Agro-Zootecnici e Forestali. \\ Università di Bari, Italy
}

Corresponding author: Prof. Angela Gabriella D’Alessandro. Dipartimento PROGESA. Università di Bari. Via G. Amendola 165/A, 70126 Bari, Italy - Tel. +39 0805442524 - Fax: +39 0805442828 - Email: dalex@agr.uniba.it

Paper received July 7, 2004; accepted February 2, 2005

\begin{abstract}
The influence of the period of semen collection on post-thawing survival, motility and acrosome integrity of spermatozoa in Leccese rams was studied throughout an entire year. The year was divided into the seasons: winter and spring (first semester) and summer and autumn (second semester). Semen from 5 adult rams was collected every two weeks by artificial vagina and frozen according to a freezing system based on milk-lactose egg yolk to constitute semen doses of 400 $x 10^{6}$ spermatozoa. At thawing, survival and acrosomal status of cells were assessed and the motility of the sperm and their kinetic rating (scale 0 to 5 score) were determined at thawing $(0 \mathrm{~h})$, and after 1 and $3 \mathrm{~h}$ incubation $\left(37^{\circ} \mathrm{C}\right)$. Semen collected during the first semester (winter - spring) of the year showed the highest $(P<0.01)$ proportion of postthaw live spermatozoa, with the maximum value in winter $(P<0.01)$, and the best acrosomal status of spermatozoa, considered as both total proportion of spermatozoa with acrosome break down and spermatozoa without acrosomes. Acrosome integrity was positively correlated $(r=0.32 ; P<0.01)$ with post-thaw sperm viability.

Motility of spermatozoa at thawing was not influenced by the period of semen collection. However, after $3 \mathrm{~h}$ incubation sperm motility was higher $(P<0.01)$ during the first semester of the year, without a difference between winter and spring. A marked individual ram effect was found on freezability of semen.

The results provide evidence that the period of semen collection can influence freezability of spermatozoa in Leccese rams. The best characteristics of spermatozoa were observed during the first semester of the year, corresponding to the sexual hypoactivity season for this breed.
\end{abstract}

Key Words: Sheep-male reproduction, Seasonal dynamics, Cryopreservation.

\section{RIASSUNTO \\ CARATTERISTICHE POST-SCONGELAMENTO DEGLI SPERMATOZOI DI ARIETI DI RAZZA LECCESE CONGELATI IN STAGIONI DIFFERENTI CON L'IMPIEGO DI UN MESTRUO \\ A BASE DI LATTE E TUORLO D'UOVO}

Lo studio, condotto per un intero anno, ha avuto lo scopo di valutare l'influenza della stagione di raccolta del seme sulla sopravvivenza post-scongelamento, sulla motilità e sull'integrità acrosomiale degli spermatozoi di arieti di razza Leccese. Sono state considerate le stagioni: inverno e primavera (primo semestre) ed estate e autunno (secondo semestre). Cinque arieti adulti sono stati sottoposti alla raccolta del seme, mediante vagina artificiale. Il seme è stato sottoposto a congelamento utilizzando un mestruo diluitore a base di latte e tuorlo d'uovo e sono state costituite dosi da $400 \times 10^{6}$ spermatozoi. Allo scongelamento è stata valutata la sopravvivenza e lo status acrosomiale degli spermatozoi, mediante doppia fluorocromatizzazione (Hoechst 33258 e FITC-PSA). La percentuale di spermatozoi mobili e la motilità individua- 
le degli spermatozoi (motilità progressiva; scala 0 - 5) è stata valutata allo scongelamento (0 ore), dopo 1 e 3 ore di incubazione $\left(37^{\circ} \mathrm{C}\right)$.

Il seme raccolto durante il primo semestre dell'anno (inverno-primavera) ha evidenziato la più elevata $(P<0,01)$ percentuale di spermatozoi vivi allo scongelamento, con il valore massimo in inverno $(P<0,01)$. Anche lo status acrosomiale, considerato come percentuale totale di spermatozoi con acrosoma danneggiato e spermatozoi privi di acrosoma, è risultato migliore $(P<0,01)$ durante il primo semestre. L'integrità acrosomiale è risultata positivamente correlata $(r=0,32$; $P<0,01)$ con la vitalità post-scongelamento degli spermatozoi.

La motilità allo scongelamento non è stata influenzata dalla stagione di raccolta del seme. Tuttavia, dopo l'incubazione per 3 ore, la motilità è stata maggiore $(P<0,01)$ durante il primo semestre dell'anno, senza differenza fra l'inverno e la primavera. Sussiste una marcata variabilità individuale per la congelabilità del seme.

I risultati hanno evidenziato che la stagione di raccolta del seme influenza la congelabilità degli spermatozoi negli arieti di razza Leccese. Le migliori caratteristiche di congelabilità degli spermatozoi sono state osservate durante il primo semestre dell'anno, in corrispondenza della stagione di ipoattività sessuale per questa razza.

Parole chiave: Caratteristiche spermatozoi, Variazioni stagionali, Congelamento, Ariete.

\section{Introduction}

The remarkable success obtained in the cryopreservation of spermatozoa in bull semen is not applicable to other species of productive interest, such as sheep, for example. It has been reported that there are two main causes for different results between the species: (i) the physiology and biochemistry of the spermatozoa, and (ii) different characteristics in the anatomy and physiology of sperm transport in the female tract (Holt, 2000a). In ewes, the anatomical conformation of the cervix blocks catheter insertion for the direct intrauterine deposition of semen. Thus, cervical insemination is generally performed on the posterior vagina and it requires semen doses with high sperm concentration, that is large numbers of spermatozoa in a small volume (Allison and Robinson, 1971; Salamon, 1977; Colas, 1983). Cervical insemination using frozen-thawed spermatozoa generally results in low fertility (Colas, 1983; Maxwell and Watson, 1996; Salamon and Maxwell, 2000; Yoshida, 2000). It is well known that cryopreservation techniques cause extensive sperm mortality through the processes of cooling, freezing and thawing (Watson, 1995, 2000; Salamon and Maxwell, 2000). For this, the quality of spermatozoa and their aptitude to the freezing process assume a critical importance and a lower tolerance of poor sperm is required in the collection of semen which have to be frozen, in order to obtain success from AI.

Several studies on rams in temperate zones have demonstrated seasonal variations that affect reproductive activity (Poulton and Robinson, 1987;
Martin et al., 1990; Perez et al., 1997; Martemucci et al., 2000), as well as freezability of spermatozoa (Maxwell, 1980; Curnock et al., 1984; D’Alessandro and Martemucci, 2003) and their fertilizing ability (Colas and Brice, 1976; Guerin et al., 1992).

This study was conducted on Leccese rams, an autochtonous breed, to investigate the effects of the period of semen collection on post-freezing survival and acrosome integrity of spermatozoa frozen in straws with a milk-lactose-egg yolk extender, in order to establish the optimal season of freezing semen to be employed in AI.

\section{Material and methods}

\section{Collection, diluent and storage of semen}

Semen was collected for a period of one year from 5 adult Leccese rams reared in semi-intensive conditions on the farm of the Faculty of Agricultural Science, Bari University (Southern Italy, $41^{\circ} \mathrm{N}$ latitude). The rams were subjected to a rhythm of semen collection twice a week by artificial vagina and assessment of the quantitative and qualitative characteristics of the semen from each ram were evaluated every two weeks.

Only ejaculates of good quality (sperm concentration $\geq 3 \times 10^{9}$ spermatozoa / mL; motility score $>4 / 5$ of a scale from 1 to 5 ; proportion of motile cells $>60 \%$ ) were processed for freezing.

For the study, semen was frozen according to a freezing method based on the use of milk - lactose egg yolk extender (Colas, 1975). Briefly, semen was pre-diluted (1:1, semen : diluent) and then diluted to a concentration of $1.5 \times 10^{9}$ spermatozoa / mL with the unglycerolate diluent containing lactose 
$(8.24 \%, \mathrm{wt} / \mathrm{v})$ and egg yolk $(20 \%, \mathrm{v} / \mathrm{v})(\mathrm{pH}=6.65$ to $6.70 ; 450 \mathrm{mOsm})$. After $2 \mathrm{~h}$ of gradual cooling to $4^{\circ} \mathrm{C}$, the glycerolate diluent - made of skim milk $(14 \%, \mathrm{wt} / \mathrm{v})$, sulphanilamide $(17.4 \mathrm{mM})$, trisodium citrate (x $\left.5.5 \mathrm{H}_{2} \mathrm{O}, 6 \mathrm{mM}\right)$, glycerol $(10 \%$, v/v) and antibiotics - was added in a volume equal to 2 / 5 of the final volume to achieve a sperm concentration of $900 \times 10^{6}$ spermatozoa / mL. Thus, semen was loaded into $0.5 \mathrm{~mL}$ French straws (IMV) constituting doses of $400 \times 10^{6}$ spermatozoa / straw, which were frozen for $7 \mathrm{~min}$ in nitrogen vapor $\left(-75^{\circ} \mathrm{C}\right)$ and then stored in liquid nitrogen $\left(-196^{\circ} \mathrm{C}\right)$ until used.

Assessment of survival and acrosome integrity

The straws were thawed in a water bath $\left(37^{\circ} \mathrm{C}\right)$ for $30 \mathrm{sec}$.

The assessment was performed by dual staining with Hoechst 33258 (Sigma; Milan, Italy) and fluorescein isothiocyanate labelled Pisum Sativum Agglutinin (FITC - PSA, Sigma), as described by Cross et al. (1986), with some modifications (D'Alessandro and Martemucci, 2003). Hoechst 33258 is a fluorescent dye which stains the dead cells blue, binding to DNA, while FITC-PSA binds to glycoproteins of acrosome, and stains sperm acrosome green, with variable colour intensity depending on the level of acrosome integrity. Spermatozoa with acrosome breakdown were classified as: sperm without acrosome (cells completely unstained), sperm with damaged acrosome (cells with patchy fluorescence) and unviable sperm with widespread fluorescence (cells completely fluorescing: head, post-acrosomial region and principal piece of tail or whole tail). Acrosome intact sperm appear with the acrosome cap fluorescing (bright green). Total spermatozoa with acrosome breakdown, including all forms of acrosome breakdown, was also reported.

\section{Assessment of motility}

Sperm motility was evaluated as proportion of motile spermatozoa and motility score, under a microscope fitted to a warm stage $\left(37^{\circ} \mathrm{C}\right)$. For the assessment, the samples were transferred to phosphate buffered saline (PBS) and motility was evaluated at $0 \mathrm{~h}$ (thawing) and after 1 and $3 \mathrm{~h}$ incubation $\left(37^{\circ} \mathrm{C}\right)$, maintaining the semen in PBS for the incubation period.
The proportion of motile sperm was determined on 40 cells of the Makler counting chamber under a phase contrast microscope (x 200) fitted with a stage warmer at $37^{\circ} \mathrm{C}$. Motile spermatozoa were determined as the difference between the total number of spermatozoa and the immotile spermatozoa, with the aid of a Polaroid freezeframe video recorder connected to a microscope (D'Alessandro and Martemucci, 2003). Motility score was determined microscopically (x 400) with a drop of diluted semen (1:100 in PBS), at thawing, after $1 \mathrm{~h}$ and again after $3 \mathrm{~h}$ incubation $\left(37^{\circ} \mathrm{C}\right)$ period using the scale 0 to 5 (0: no motion; 5 : very rapid forward motion).

The experimental data were referred as: seasonal mean values, where season was the months of January - February - March as Winter, April May - June as Spring, July - August - September as Summer and October - November - December as Autumn; means of both the first semester of the year, from January to June, and the second semester, from July to December.

\section{Statistical analyses}

Prior to statistical analysis, the data were tested for homogeneity of variance by the Bartlett's test and, where necessary, transformed $(\log +1)$. Data were analysed by least squares analysis of variance using the GLM procedure of the SAS system (SAS, 1987). The statistical model used considered the effects of season, month of semen collection, animal and their interactions. Least squares means between seasons were compared by the $\mathrm{T}$ value (PDIFF option), while a comparison between semesters was made by linear contrast. Correlation between the different parameters were also determined by regression analysis (SAS, 1987).

\section{Results}

The period of semen collection significantly influenced $(\mathrm{P}<0.01)$ post-thaw survival of the spermatozoa. The proportion post-thaw live spermatozoa was higher $(\mathrm{P}<0.01)$ when semen was collected in winter and spring and this corresponded to a higher $(\mathrm{P}<0.01)$ post-thaw survival rate of sperm during the first semester (Table 1). 
Table 1. Effects of the period of semen collection on the post-freezing live spermatozoa (mean $\pm \mathrm{SE}$ ).

\begin{tabular}{|c|c|}
\hline Period & Live sperm (\%) \\
\hline Winter & $48.2 \pm 1.6^{A}$ \\
\hline Spring & $42.2 \pm 1.6^{c}$ \\
\hline Summer & $36.2 \pm 1.6^{B}$ \\
\hline Autumn & $40.3 \pm 1.7^{\mathrm{BC}}$ \\
\hline $1^{\text {st }}$ Semester ${ }^{1}$ & $45.2 \pm 1.3^{\circ}$ \\
\hline $2^{\text {nd }}$ Semester ${ }^{2}$ & $38.3 \pm 1.4^{\mathrm{E}}$ \\
\hline $\begin{array}{l}{ }^{1} \text { January to June } \\
{ }^{2} \text { July to December } \\
A, B, C \text { Significant differences among the seasons }(P<0.01)\end{array}$ & \\
\hline
\end{tabular}

The detrimental effect of the second semester of the year on sperm viability was most evident in summer (Table 1). The ram effect was significant $(\mathrm{P}<0.05)$ with respect to the survival of spermatozoa at thawing.

Total proportion of spermatozoa with acrosome breakdown was significantly $(\mathrm{P}<0.01)$ influenced by the season of semen collection and individual ram effect. The lowest $(\mathrm{P}<0.01)$ incidences of acrosomal breakdown were observed in semen collected during the first semester, and particularly in spring $(\mathrm{P}<0.01)$ (Table 2$)$.

The proportion of spermatozoa with intact acrosomes at thawing resulted positively correlated $(\mathrm{P}<0.01)$ to proportions of post-thaw live sperm $(\mathrm{r}=0.32)$.

Also the proportion of spermatozoa without acrosomes was significantly $(\mathrm{P}<0.01)$ influenced by the season of semen collection and ram effect. The incidence of spermatozoa without acrosome was higher in the second semester $(\mathrm{P}<0.01)$, with the highest occurrence in summer $(\mathrm{P}<0.01)$ (Table 2$)$.

The proportion of spermatozoa with acrosomal damage was influenced $(\mathrm{P}<0.01)$ by the month of collection, but the effect of season was not significant. There were no differences in proportions of sperm with acrosomal damage between the two semesters and values were similar for all seasons. The proportions of sperm without acrosome and sperm with damaged acrosome were positively correlated $(\mathrm{r}=0.30 ; \mathrm{P}<0.01)$ only when considering the entire year.

Of the total acrosome abnormalities, the proportion showing widespread FITC-PSA fluorescence was the least influential, with values ranging between $0.1 \%$ (winter) to $0.8 \%$ (spring and autumn; $\mathrm{P}<0.01$ ).

The motility of sperm was not influenced by the season of semen collection, but the effect of the individual was significant $(\mathrm{P}<0.01)$ after $3 \mathrm{~h}$ of incubation. The proportion of motile sperm, ranged from 35.1 to $38.1 \%$ at thawing, and decreased with time of incubation (Table 3 ). After $3 \mathrm{~h}$ of incubation sperm motility during the first semester of the year was higher $(\mathrm{P}<0.01)$, with similar values in winter and spring $(\mathrm{P}<0.01)$ (Table 3).

The proportion of motile sperm after $3 \mathrm{~h}$ of incubation was negatively correlated with sperm motility at thawing $(\mathrm{r}=-0.27 ; \mathrm{P}<0.05)$.

The motility score of sperm followed the same trend as motility (Table 4). After $3 \mathrm{~h}$ of incubation, motility score (scale 0 to 5) ranged from 3.04 to 3.26 for the different seasons. 
Table 2. Effects of the period of semen collection on the post-freezing acrosome status of spermatozoa (mean $\pm \mathrm{SE}$ ).

\begin{tabular}{|c|c|c|c|c|}
\hline Period & $\begin{array}{l}\text { Total spermatozoa } \\
\text { with acrosome } \\
\text { breakdown } \\
(\%)\end{array}$ & $\begin{array}{l}\text { Spermatozoa } \\
\text { without } \\
\text { acrosome } \\
(\%)\end{array}$ & $\begin{array}{l}\text { Spermatozoa } \\
\text { with damage } \\
\text { of acrosome } \\
(\%)\end{array}$ & $\begin{array}{l}\text { Unviable spermatozoa } \\
\text { with widespread } \\
\text { fluorescence } \\
(\%)\end{array}$ \\
\hline Winter & $69.5 \pm 2.0^{\mathrm{BC}}$ & $28.2 \pm 1.4^{\mathrm{B}}$ & $40.9 \pm 2.1$ & $0.1 \pm 0.1^{A}$ \\
\hline Spring & $65.3 \pm 1.9^{c}$ & $29.3 \pm 1.4^{\mathrm{B}}$ & $35.1 \pm 2.1$ & $0.8 \pm 0.1^{\mathrm{B}}$ \\
\hline Summer & $85.1 \pm 2.0^{A}$ & $44.1 \pm 1.4^{A}$ & $40.4 \pm 2.2$ & $0.5 \pm 0.1$ \\
\hline Autumn & $74.3 \pm 2.1^{\mathrm{B}}$ & $34.3 \pm 1.5^{c}$ & $39.1 \pm 2.3$ & $0.8 \pm 0.1^{\mathrm{B}}$ \\
\hline $1^{\text {st }}$ Semester ${ }^{1}$ & $67.4 \pm 1.4^{\mathrm{D}}$ & $28.8 \pm 1.2^{D}$ & $38.0 \pm 1.5$ & $0.5 \pm 0.07$ \\
\hline $2^{\text {nd }}$ Semester ${ }^{2}$ & $79.7 \pm 1.5^{\mathrm{E}}$ & $39.2 \pm 1.3^{\mathrm{E}}$ & $39.7 \pm 1.6$ & $0.7 \pm 0.08$ \\
\hline \multicolumn{5}{|c|}{$\begin{array}{l}{ }^{1} \text { January to June } \\
2 \text { July to December } \\
A, B, C \text { Significant differences among the seasons }(P<0.01) \\
D, E \text { Differences between the two semesters }(P<0.01)\end{array}$} \\
\hline
\end{tabular}

\section{Discussion}

A large number of techniques have been tested in order to reduce or stop the metabolism of spermatozoa, thereby prolonging their fertile life. This is commonly achieved by cryopreservation (Maxwell and Salamon, 1993) and different extenders have been tested to freeze ram semen in an attempt to minimize detrimental effects of the freezing process on sperm (Salamon and Maxwell, 1995a; 2000). The main physiological and functional changes in spermatozoa which occur include an irreversible reduction in viability, acrosome integrity, motility and thus, fertility (Salamon and Maxwell, 2000; Medeiros et al., 2002). The sperm capability to resist cold shock, generally known as freezability, is an important requirement to maintain the plasma and outer acrosomal membranes intact and undamaged throughout cryopreservation and thawing. There is evidence that freezability of sperm is affected by season within breeds (Maxwell, 1980; Curnock et al., 1984).

It has been established that the optimal conditions for semen freezing may differ with the osmotic pressure, composition of extenders and the dilution rate of the semen (Ritar and Ball, 1993; D'Alessandro et al., 2001a; El-Alamy and Foote, 2001). Previous studies performed on Leccese rams have evaluated seasonal variations in the quality of fresh semen (D'Alessandro et al., 2001a) and semen freezability using a freezing method based on Tris - fructose egg yolk extender to constitute semen doses of $100 \times 10^{6}$ sperm (D'Alessandro and Martemucci, 2003). In the present study the seasonal variation in the freezability of spermatozoa using a freezing system based on a milk - lactose egg yolk as extender was used (Colas, 1975) to constitute semen doses of $400 \times 10^{6}$ spermatozoa suitable for cervical inseminations.

The results of this experiment indicate that spermatozoa ejaculated during winter and spring (corresponding to the non-breeding season; Martemucci et al., 1979), have a higher ability to survive freezing and a better acrosomal integrity than semen frozen during the second semester. Contrary to these findings, in fresh semen a higher survival rate of sperm was observed during the second semester (D'Alessandro et al., 2001b) due to the positive effect of decreasing photoperiod on 
Table 3. Effects of the period of semen collection on the percentage of motile spermatozoa at thawing $(0 \mathrm{~h})$ and during the post-thawing incubation $\left(37^{\circ} \mathrm{C}\right)$ for 1 and $3 \mathrm{~h}$ (mean $\pm \mathrm{SE})$.

\begin{tabular}{|c|c|c|c|}
\hline \multirow[b]{2}{*}{ Period } & \multicolumn{3}{|c|}{ Motile spermatozoa (\%) after incubation for } \\
\hline & $\mathrm{Oh}$ & $1 \mathrm{~h}$ & $3 \mathrm{~h}$ \\
\hline Winter & $35.1 \pm 2.7$ & $24.2 \pm 2.3$ & $14.6 \pm 1.3^{A}$ \\
\hline Spring & $35.1 \pm 2.3$ & $22.9 \pm 2.0^{b}$ & $14.3 \pm 1.1^{A}$ \\
\hline Summer & $33.9 \pm 2.3$ & $22.8 \pm 2.0^{\mathrm{b}}$ & $9.6 \pm 1.1^{\mathrm{B}}$ \\
\hline Autumn & $38.1 \pm 2.5$ & $29.2 \pm 2.1^{\mathrm{a}}$ & $12.6 \pm 1.2$ \\
\hline $1^{\text {st }}$ Semester ${ }^{1}$ & $35.1 \pm 2.6$ & $23.6 \pm 1.7$ & $14.5 \pm 1.0^{\circ}$ \\
\hline $2^{\text {nd }}$ Semester ${ }^{2}$ & $36.9 \pm 2.1$ & $26.0 \pm 1.6$ & $11.1 \pm 0.9^{\mathrm{E}}$ \\
\hline \multicolumn{4}{|c|}{$\begin{array}{l}{ }^{1} \text { January to June. } \\
{ }^{2} \text { July to December } \\
A, B ; a, b \text { Significant differences among the seasons }(A-B: P<0.01 ; a-b: P<0.05)\end{array}$} \\
\hline
\end{tabular}

Table 4. Effects of the period of semen collection on the post-freezing kinetic rating (scale 0 to 5 ) of spermatozoa at thawing $(0 \mathrm{~h})$ and after 1 and $3 \mathrm{~h}$ incubation $\left(37^{\circ} \mathrm{C}\right)$ (mean $\left.\pm \mathrm{SE}\right)$.

\begin{tabular}{|c|c|c|c|}
\hline \multirow[b]{2}{*}{ Period } & \multicolumn{3}{|c|}{ Kinetic rating after incubation for } \\
\hline & $\mathrm{Oh}$ & $1 \mathrm{~h}$ & $3 \mathrm{~h}$ \\
\hline Winter & $4.17 \pm 0.10$ & $3.7 \pm 0.2$ & $3.02 \pm 0.20$ \\
\hline Spring & $4.15 \pm 0.09$ & $3.9 \pm 0.1$ & $3.26 \pm 0.16$ \\
\hline Summer & $4.06 \pm 0.09$ & $3.7 \pm 0.1$ & $3.04 \pm 0.16$ \\
\hline Autumn & $4.23 \pm 0.09$ & $3.9 \pm 0.2$ & $3.24 \pm 0.17$ \\
\hline $1^{\text {st }}$ Semester ${ }^{1}$ & $4.16 \pm 0.08$ & $3.8 \pm 0.1$ & $3.14 \pm 0.14$ \\
\hline $2^{\text {nd }}$ Semester ${ }^{2}$ & $4.14 \pm 0.08$ & $3.8 \pm 0.1$ & $3.14 \pm 0.13$ \\
\hline $\begin{array}{l}{ }^{1} \text { January to June } \\
{ }^{2} \text { July to December }\end{array}$ & & & \\
\hline
\end{tabular}


sexual activity of rams (Colas, 1980; Mickelsen et al., 1981; Dufour et al., 1984). This pattern has also been observed in frozen semen processed with a Tris - fructose egg yolk extender (D'Alessandro and Martemucci, 2003). No explanation can be offered for these findings. It is possible that specific components of the milk - lactose egg yolk extender and their concentrations have preserved the plasmatic membrane integrity, index of sperm viability, as well as the acrosomal membrane. It was reported that milk diluents contain several compounds which act positively on spermatozoa viability (Salamon and Maxwell, 1995a). In the extender used in this study the proportion of egg yolk ranged from 2.2 to $10.2 \%$. The protective effect of egg yolk has been attributed to the low protein density fraction, specifically the phospholipids, a high molecular weight component, which act at the cell surface (Watson, 1975). Loss of phospholipids from sperm membrane is assumed to occur during cold shock (Parks and Graham, 1992). In addition, it has been reported that egg yolk also protects against lipid peroxidation (Marwell and Stojanov, 1996), induced by cryopreservation (Alvarez and Storey, 1992; Bell et al., 1993; O'Flaherty et al., 1997) thus acting as an antioxidant. Furthermore, there is the possibility that the positive effects due to addition of milk lipoproteins enhance those of the egg yolk on the sperm surface. All this may compensate for the lower amount of proteins in sperm membranes attributed to the adverse breeding season (Smith et al., 1999) combined with the loss due to the freezing process (Centola et al., 1990; Ollero et al., 1998), probably acting on the distribution and/or interaction of lipids and proteins within the plasma membrane. It must be taken into account that cryoresistance is related to the composition of the plasma membrane (Parks and Graham, 1992) and that acrosomal plasma membranes may differ in their composition (Holt and North, 1985). The positive correlation between post-thawing viability and acrosomal integrity of the sperm confirmed what was reported in previous studies (Valcarcel et al., 1997; D'Alessandro and Martemucci, 2003).

Considering the different classes of the acrosome status in sperm, the results indicate a higher incidence of acrosome damage, corresponding to the patchy FITC-PSA fluorescence. The patchy flu- orescence of the acrosome membrane is indicated as acrosome reaction in progress (Sukardi et al., 1997). The lack of differences among the seasons could demonstrate that there is an effect due only to the cryopreservation process, which induces a status similar to capacitation and acrosome reaction (Watson, 1995, 1996; Maxwell and Watson, 1996). The loss of acrosome, index of complete sperm capacitation (Sukardi et al., 1997) and shorter life of spermatozoa (Watson, 1995, 1996; Maxwell and Watson, 1996), was highest in summer, the season in which the spermatozoa show the lowest qualitative characteristics. Sperm with widespread flourescence in the whole cell was very low $(<1 \%)$. This form of staining can be due to the effect of a long permeabilization of cellular membrane during the staining procedure, which causes loss in bond selectivity of PSA for the acrosomal components, or to a higher availability for the PSA of non acrosomal bond sites in dead cells (Mendoza et al., 1992).

Motility of spermatozoa at thawing was not affected by the period of semen collection at thawing, while after $3 \mathrm{~h}$ incubation the negative influence of the second semester, especially in summer, was evident. It is possible to conclude that the extender used in the freezing process could be adequate to compensate for the different qualitative sperm characteristics induced by the period of the year (D'Alessandro et al., 2001a). Incubation highlights different modifications of cell structures and functions connected with the motility of sperm. It is noteworthy that in a previous study (D'Alessandro and Martemucci, 2003) on the same Leccese rams, using a Tris - fructose egg yolk extender (final concentration of $100 \times 10^{6}$ spermatozoa), motility of spermatozoa was lower than that obtained in the present study with a milklactose-egg yolk-based extender. These findings are in agreement with the studies of D'Alessandro et al. (2001b) where the same milk - lactose egg yolk extender displayed a better protective effect on sperm motility after thawing, compared to the Tris - fructose egg yolk extender at the pre-freezing sperm concentrations between 50 to $400 \times 10^{6}$ spermatozoa/ $\mathrm{mL}$ (inseminate doses of 10 to $80 \mathrm{x}$ $10^{6}$ spermatozoa). This could be attributed to the higher osmolarity of the extender (450 vs 300 to $326 \mathrm{mOsm}$, milk vs Tris based extender), which in 
buck semen has been linked to the better tolerance of spermatozoa at all dilution rates compared to hypotonic diluents (Ritar and Ball, 1993).

The results of this study also confirm the interindividual differences in sperm freezability found in other research (Maxwell, 1986; Butler and Maxwell, 1988; Eppleston and Maxwell, 1991) which can be attributed to both genetic and environmental conditions (Salamon and Maxwell, 1985b; Holt, 2000b).

In conclusion, the results indicate that period of semen collection influences freezability of spermatozoa in Leccese rams. The post-freezing characteristics of sperm are higher during the first semester of the year (winter - spring), which in the experimental conditions coincides with the period of sexual hypoactivity.

\section{Conclusions}

The results show that in Leccese rams the period of semen collection influence freezability of spermatozoa. Overall, the best freezability characteristics of spermatozoa, using milk-lactose-egg yolk extender, occur during the first semester of the year (winter to spring), corresponding to the sexual hypoactivity season for this breed.

The authors gratefully acknowledge L. Basso and D. D'Elia for their technical assistance and $P$. Cataldo for laboratory analyses.

This research was supported by Università di Bari, Italy (ex MURST 60\%)

\section{REFERENCES}

Allison, A.J., RoBinson, T.J., 1971. Fertility of progestagen-treated ewes in relation to the numbers and concentration of spermatozoa in the inseminate. Aust. J. Biol. Sci. 24:1001-1008.

Alvarez, J.G., STOREY, B.T., 1992. Evidence for increased lipid peroxidative damage and loss of superoxide dismutase activity as a mode of sublethal cryodamage to human sperm during cryopreservation. J. Androl. 13:232-241.

Bell, M., Wang, R., Hellstrom, W.J., SikKa, S.K., 1993. Effect of cryoprotective additivies and cryopreservation protocol on sperm membrane lipid peroxidation and recovery of motile human sperm. J. Androl. 14:472-478.

Butler, L.G., MaXwell, W.M.C., 1988. The effects of sire and location on results of on-farm intrauterine insemination of frozen-thawed semen. Proc. Aust. Assoc. Anim. Breed. Genet. 7:394-397.

Centola, G.M., Mattox, J.H., Burde, S., Leary, J.F., 1990. Assessment of the viability and acrosome status of fresh and frozen-thawed human spermatozoa using single-wavelength fluorescence microscopy. Mol. Reprod. Dev. 27:130-135.

ColAs, G., 1975. Effect of initial freezing temperature, addition of glycerol and dilution on the survival and fertilizing ability of deep-frozen ram semen. J. Reprod. Fertil. 42:277-285.

ColAs, G., 1980. Variations saisonnières de la qualité du sperme chez le belier Ile-de-France. I. Etude de la morphologie cellulaire et de la motilité massale. Reprod. Nutr. Dev. 20:1789-1799.

ColAS, G., 1983. Factors affecting the quality of ram semen. In: W. Haresign (ed.) Sheep production. Butterworths, London, pp 453-465.

Colas, G., Brice, G., 1976. Seasonal variations of the fertilizing capacity of deep-frozen ram semen. pp 977-980 in Proc. $8^{\text {th }}$ Int. Congr. Anim. Reprod. and AI, Crakow, Poland.

Cross, N.L., Morales,P., Overstreet, J.W., Hanson, F.W., 1986. Two simple methods for detecting acrosome reacted human sperm. Gamete Res. 15:213-226.

CuRnock, R.M., ReED, H.C.B., Logue, D.N., MAXwell, W.M.C., 1984. Artificial insemination of ewes with ram semen frozen by the pellet method. Anim. Prod. 38:546 (abstr.).

D'Alessandro, A.G., MARTEMucCI, G., 2003. Evaluation of seasonal variations of semen freezability in Leccese ram. Anim. Reprod. Sci. 79:93-102.

D’Alessandro, A.G., Colonna, M.A., Bellitti, A., MARTEMUCCI, G., 2001a. Variazioni durante l'anno delle caratteristiche quantitative e qualitative del seme in arieti di razza Leccese. Zoot. Nutr. Anim. 27:221-230.

D’Alessandro, A.G., Martemucci, G., Colonna, M.A., BellitTi, A., 2001b. Post-thaw survival of ram spermatozoa and fertility after insemination as affected by pre-freezing sperm concentration and extender composition. Theriogenology. 55:1159-1170.

Dufour, J.J., FAhmy, M.H., Minvielle, F., 1984. Seasonal changes in breeding activity, testicular size, testosterone concentration and seminal characteristics in rams with long or short breeding season. J. Anim. Sci. 58:416-422.

El-Alamy, M.A., Foote, R.H., 2001. Freezability of spermatozoa from Finn and Dorset rams in multiple semen extenders. Anim. Reprod. Sci. 65:245-254.

EpPleston, J., MAXwELL, W.M.C., 1991. Between ram variation in the reproductive performance of ewes 
inseminated with frozen semen. Proc. Aust. Soc. Reprod. Biol., 23:130 (abstr.).

GuÉRIn, Y., Cognié, Y., Poulin, N., 1992. Freezability of freshly ejaculated and frozen ram semen in vitro. pp 1418-1420 in Proc. $12^{\text {th }}$ Int. Congr. Anim. Reprod., The Hague, The Netherlands.

Holt, W.V., 2000a. Basic aspects of frozen storage of semen. Anim. Reprod. Sci. 62:3-22.

Holt, W.V., 2000b. Fundamental aspects of sperm cryobiology: the importance of species and individual differences. Theriogenology. 53:47-58.

Holt, W.V., NoRTh, R.D., 1985. Determination of lipid composition and thermal phase transitions temperature in an enriched membrane fraction from ram spermatozoa. J. Reprod. Fertil. 73:285-294.

Martemucci, G., Gambacorta, M., Melodia L., Zezza, L., 1979. Studio sull'attività sessuale della pecora Leccese. Ann. Facoltà di Agraria dell'Università di Bari. 32:217-226.

Martemucci, G., Facciolongo, A.M., Bramante, G., 2000. Variazioni durante l'anno delle dimensioni testicolari, della libido e della testosteronemia successiva a stimolazione con $\mathrm{Gn}-\mathrm{RH}$ in arieti di razza Leccese. Zoot. Nutr. Anim. 26:199-209.

Martin, G.B., Ford, J.R., Purvis, I.W., 1990. Environmental and genetics factors affecting reproductive activity in the Merino ram. In: C.M. Oldham, G.B. Martin and I.W. Purvis (eds.) Reproductive Physiology of Merino Sheep: Concepts and Consequences. School of Agriculture (Animal Science) of The University of Western Australia ed., Perth, Australia, pp 111-129.

MAXWELL, W.M.C., 1980. Fertility of ram semen frozen in autumn and spring. Proc. Aust. Soc. Reprod. Biol. 12:8 (abstr.).

MAXWELL, W.M.C., 1986. Artificial insemination of ewes with frozen-thawed semen at a synchronized oestrus. 2. Effect of dose of spermatozoa and site of insemination on fertility. Anim. Prod. Sci. 10:301-308.

MaXwell, W.M.C., SAlamon, S., 1993. Liquid storage of ram semen: a review. Reprod. Fert. Dev. 5:613638.

MAXWELl, W.M.C., Stojanov, T., 1996. Liquid storage of ram semen in the absence or presence of some antioxidant. Reprod. Fertil. Dev. 8:1013-1020.

MAXWELL, W.M.C., WATSON, P.F., 1996. Recent progress in the preservation of ram semen. Anim. Reprod. Sci. 42: 55-65.

Medeiros, C.M.O., Forell, F., Oliveira, A.T.D., RODRIGUEZ, J.L., 2002. Current status of sperm cryopreservation: why isn't it better? Theriogenology. 57:327-344.

Mendoza, C., Carreras, A., Moss, J., Tesarik, J., 1992. Distinction between true acrosome reaction and degenerative acrosome loss by one-step staining method using Pisum sativum agglutinin. J. Reprod. Fertil. 95:755-763.
Mickelsen, W.D., Paisley, L.G., Dahmen, J.J., 1981. The effect of season on the scrotal circumference and sperm motility and morphology in rams. Theriogenology. 16:45-51.

O'Flaherty, C., Beconi, M., Beorlegui, N., 1997. Effect of natural antioxidants, superoxide dismutase and hydrogen peroxide on capacitation of frozen-thawed bull spermatozoa. Andrology. 29:269-275.

Ollero, M., Bescós, O., Cebrián-Perez, J.A., MuiñoBiAnco, T., 1998. Loss of plasma membrane proteins of bull spermatozoa through the freezingthawing process. Theriogenology. 49:547-555.

PARKS, J.E., GRAHAM, J.K., 1992. Effects of cryopreservation procedures on sperm membranes. Theriogenology. 38:209-222.

Pérez, R., Lòpez, A., CAstrillejo, A., Bielli, A., Laborde, D., Gastel, T., Tagle, R., Queirolo, D., Franco, J., Forsberg, M., Rodrìguez-Martìnez, H., 1997. Reproductive seasonality of Corredale rams under extensive rearing conditions. Acta Vet. Scand. 38:109-117.

Poulton, A.L., RoBinson, T.J., 1987. The response of rams and ewes of three breeds to artificial photoperiod. J. Reprod. Fertil. 79:609-626.

RITAR, A.J., BALL, P.D., 1993. The effect of freeze-thawing of goat and sheep semen at a high density of spermatozoa on cell viability and fertility after insemination. Anim. Reprod. Sci. 31:249-262.

SAlAmON, S., 1977. Fertility following deposition of equal numbers of frozen-thawed ram spermatozoa by single and double insemination. Aust. J. Agr. Res. 28:477-479.

Salamon, S., Maxwell, W.M.C., 1995a. Frozen storage of ram semen. I. Processing, freezing, thawing and fertility after cervical insemination. Anim. Reprod. Sci. 37:185-249.

Salamon, S., Maxwell, W.M.C., 1995b. Frozen storage of ram semen. II. Causes of low fertility after cervical insemination and methods of improvement. Anim. Reprod. Sci. 46:89-96.

Salamon, S., MaXwell, W.M.C., 2000. Storage of ram semen. Anim. Reprod. Sci. 62:77-111.

SAS, 1987. SAS/STAT TM Guide for Personal Computers, Version 6 Ed.. SAS Institute Inc., Cary, NC, USA.

SMith, J.F., PARR, J., MurRay, G.R., McDonald, R.M., LEE, R.S-F., 1999. Seasonal changes in the protein content and composition of ram seminal plasma. Proc. New Zealand Soc. Anim. Prod. 59:223-225.

Sukardi, S., Curry, M.R., Watson, P.F., 1997. Simultaneous detection of the acrosomal status and viability of incubated ram spermatozoa using fluorescent markers. Anim. Reprod. Sci. 46:89-96.

Valcárcel, A., De las Heras, M.A., Perez, L., Moses, D.F., Baldassarre, H., 1997. Assessment of the acrosomal status of membrane-intact ram spermatozoa after freezing and thawing, by simulta- 
neous lectin/Hoechst 33258 staining. Anim. Reprod. Sci. 45:299-309.

WATson, P.F., 1975. The interaction of egg yolk and ram spermatozoa studies with a fluorescent probe. J. Reprod. Fertil. 42:105-111.

WATson, P.F., 1995. Recent developments and concepts in the cryopreservation of spermatozoa and the assessment of their post-thawing function. Reprod. Fertil. Devel. 7:871-891.

WATson, P.F., 1996. Cooling of spermatozoa and fertilizing capacity. Reprod. Domest. Anim. 31:135-140.

WATson, P.F., 2000. The causes of reduced fertility with cryopreserved semen. Anim. Reprod. Sci. 6061:481-492.

YoshidA, M., 2000. Conservation of sperm: current status and new trends. Anim. Reprod. Sci. 6061:349-355. 